the ambiguities that allowed the government to prosecute The Progressive for publishing an article on how the hydrogenbomb works, even though it was based on material taken from public library shelves.

As Admiral Inman and others pointed out, however, the debate over the national security implications of scientific research is no longer purely a military question, linking up directly with concerns about the "export" of commercially valuable information through open publication.

"Some of our most carefully nurtured technological advances have suffered from a haemorrhage of foreign technology transfer from international trade - the licit or illicit selling of everything from chips to detailed manuals - to explicit espionage efforts", the session was told by Mr Daniel C. Schwarz, an attorney who, as general counsel to the National Security Agency, had helped draw up the proposed prepublication review procedure for cryptography research.

Admiral Inman also suggested, though emphasizing that he was expressing a personal opinion only, that there were several other fields such as computer hardware and software, lasers, crop projections and manufacturing procedures where publication of certain technical information "could affect the national security in a harmful way".

He also reacted to the charge that the National Security Agency had not provided public proof of its concerns about

\section{Relative prosperity}

A gift of $\$ 1$ million from $\mathrm{Mr}$ Harold McGraw, chairman of McGraw-Hill the publishers, has ensured that work on the Einstein papers can continue to completion. But Dr John Stachel, the editor of the project for the past four years, says that although the gift is enough to ensure continuity, more money will be needed if the staff of the project is to be increased from two (at present) to the desired four or five.

For the time being, work is concentrated on the early years of Einstein's academic life. The intention is to include not merely extant letters and published papers but also ancillary documents. Dr Stachel is pleased to have come across already a letter of commendation from Einstein's eventual colleagues at the Eidgenössische Technische Hochschule (ETH), Zurich (where Einstein went from the Patent Office in Berne) saying, in effect, that although Einstein was a Jew, he was "quite a nice Jew, not like the others".

At this stage nobody is prepared to guess how long the project will take, or how many volumes will eventually be published (by Princeton University Press) although there will certainly be a score of them. Dr Stachel expects to be working on the project for twenty years. the potential damage that could be caused by the publication of the results of cryptography by arguing that such information was often even more sensitive than the basic information itself.

"Nowhere in the scientific ethos is there any requirement that restrictions cannot, or should not, when necessary be placed on science", he said. "Scientists do not immunize themselves from social responsibility simply because they are engaged in a scientific pursuit."

He quoted several other areas, such as controls on genetic engineering research or on the protection of proprietary data, in arguing that there was nothing inherently wrong with an attempt to impose restrictions on science. "Some of these restrictions are common sense, some are federal requirements, some are simply good business and some are good science," Admiral Inman said.

David Dickson

\section{Polish crisis}

\section{Exiled students speak}

\section{Paris}

Poland's “independent student association" was disbanded last week by order of the Ministry of Science, Higher Education and Technology. According to this decision, the association was disbanded for continuing militant activity after the declaration of martial law. Activists had, it is alleged, continued to distribute leaflets calling for strikes and other protest actions which represented a "flagrant violation of the decree on martial law".

The day after the decree, a group of Polish students, stranded in the West by the declaration of martial law, set up a "coordination group of the independent student association" with a provisional office in Paris. The group intends to work mainly for the relief of academics and students interned in Poland under the martial law regulation. At a press conference in Paris last week, however, it stressed that the current situation, with the threat that oaths of loyalty must be taken by academics and students who wish to continue working in the universities, will prove disastrous for higher education in Poland.

It has therefore asked students throughout the world to press for the liberation of the interned students, and for all intellectuals to take a similar stand concerning intellectual and academic staff. In particular, it called for a boycott of scientific, economic and sporting cooperation with "representatives of Jaruzelski, Moscow and the Eastern bloc" until martial law is lifted in Poland.

One of the speakers at the conference, Miss Anna Krajewska, a philosophy student from Kracow, said that one of the major "sins" of the independent student association had been its participation in a plan to create a new international student organization independent of all political slant or affiliations.

Recent announcements by General Jaruzelski's military government has accused the association of "striving to create a new anti-socialist student international organization and at the same time to break up the existing international students' association" (a reference to the Prague-based and socialist-oriented IUS).

According to official statements in Poland, the Ministry of Science, Higher Education and Technology (which is at present without a minister) feels sure that members of the former independent student association will "judge correctly" the extremist leaders who "abuse the confidence" of rank and file students. By taking up studies, says the ministry, and "respecting the law", they can be sure of preserving their student status. This is a clear hint that the current process of political "verification" now taking place in Polish industry will be imposed on students before they are allowed to resume their studies. A meeting last week between the rectors of medical academies and political leaders suggests that in medical schools the process will be introduced even more rapidly and strictly.

Vera Rich

\section{British medical research \\ Vacancy filled?}

Dr J.D. ("Dai") Rees, from Unilever, is for the time being the Medical Research Council's preferred appointment as director of its National Institute for Medical Research at Mill Hill, in suburban London. An appointment has become necessary because Sir Arnold Burgen, the present director, is leaving in the summer to become the Master of Darwin College, Cambridge. A definite proposal has not yet been put to Dr Rees, it is understood.

Dr Rees has been connected with the Medical Research Council for the past two years, since his part-time appointment as co-director of the council's Biophysics Unit based at King's College, London. Recently he has played an important part in suggesting a new management structure for the National Institute, which has an annual budget of $£ 8$ million. Part of this proposal, on which senior staff at the institute are being consulted, is that the new director should be advised by a four-member management committee empowered to determine the general pattern of research.

Dr Rees, in his early forties, is a carbohydrate chemist by background who has established a dazzling reputation at Unilever by his work leading to the development of polysaccharides capable of lending physical structure to otherwise fluid materials. The technique is now used commercially in the manufacture of ice cream and of instant desserts.

More recently, Dr Rees has turned to cell biology, including the study of cell movement on surfaces. 
Dr Rees's obvious attractions as director at Mill Hill include his combination of individual experience with his reputation as a scientist and his formidable reputation for getting on well with people.

Among the questions to be settled before an appointment can be offered are an appropriate salary - the director of Mill Hill has traditionally been a physician whose salary has been linked with those of medically qualified academics. There is also a question of the new director's freedom to make appointments of his own.

\section{US agricultural aid}

\section{Balance for all}

\section{Washington}

A report by the General Accounting Office (GAO), the investigative arm of the US Congress, criticizes the ability of US universities to carry out agricultural research and technical assistance relevant to the needs of Third World countries.

The report, recently published in Washington, focuses on the impact of legislation passed by Congress in 1975 which directed the Agency for International Development (AID) to find ways of strengthening and improving the involvement of US universities in solving the food problems of the developing nations. The action by Congress was meant to halt the decline in AID research grants to universities which had taken place in the early 1970 s and covers projects totalling about $\$ 400$ million.

After a detailed assessment of the various initiatives taken under the new legislation, an amendment to Title XII of the Foreign Assistance Act, known as "Famine Prevention and Freedom from Hunger', the GAO concludes that progress in achieving its goal had been slow and in some cases virtually non-existent.

The debate over the relationship between AID, Third World needs and the US research community has considerable significance for US foreign policy. Increased assistance for agricultural research was one of the recommendations that won universal endorsement - including that of President Ronald Reagan - at October's summit meeting in Cancun, Mexico.

The Reagan-appointed administrators of AID, who see Title XII as providing a firm basis for switching the emphasis of foreign aid towards technical assistance, particularly in agricultural research, claim that parts of the GAO report create an impression "which seriously understates the very substantial progress made during the first five years of Title XII".

However, Mr Herbert L. Beckington, the agency's inspector general, commenting on a draft report, said that in general AID accepts its recommendations and intended to carry them out. And AID deputy administrator Mr Joseph Wheeler told a recent meeting of the Board for International Food and Agricultural Development that plans were already under way to issue a policy directive clarifying the agency's commitment to the Title XII concept and to make implementation more effective.

AID officials emphasize that the legislation was originally intended to ensure that US universities with a tradition of agricultural research received adequate support to enable them to provide technical assistance to developing nations, a capability which they claim was eroded in the early 1970 s as foreign-aid policy switched to commodity and credit agreements. They accept many of the criticisms of the way in which technical assistance programmes have worked out in practice. The GAO investigators, for example, found that many AID field missions distrusted teams sent out by US universities, claiming that members of such teams often lacked relevant experience of the problems they were meant to tackle.

The GAO report also criticizes the AID contract procedures in universities. In some cases, for example, it is claimed that the agency has taken up to two years to approve the award of a contract to a particular university. In addition, it says that the resource registry used to identify the best institutions and individual resources is not up to date, contains inadequate information and is cumbersome to use.

Supporters of Title XII within AID, who feel that their efforts to implement the legislation effectively received only lukewarm support from the Carter Administration, have generally welcomed the GAO report and hope that the new Administration will prove more sympathetic.

David Dickson

\section{Drug regulation in Brazil}

\section{Troubles building}

\section{Rio de Janeiro}

The inauguration last month of a new headquarters for Brazil's National Institute for Health Quality Control underlines the urgent need to bring order to the chaotic system of marketing pharmaceuticals in Brazil. Over the past ten years, Brazil has licensed on average 8,000 new brand names for drugs each year and the country is among the most liberal in the developing world for allowing the exploitation of pharmaceutical products.

Brazil now ranks sixth in the world for pharmaceutical sales, and the market is dominated by the multinational companies which lobby in Brasilia against tighter regulatory measures. Import licences are issued by the Ministry of Commerce which registered US $\$ 5.5$ million of "pharmaceutical drug imports" and $\$ 300$ million under the category "other pharmaceutical additives" during the first three months of 1981. Total sales last year amounted to almost $\$ 2,000$ million, or six times the amount spent for all public health programmes in the country.

Last month Brazil's president, General
Figueiredo, opened a new $\$ 5$ million sevenpoint star-shaped building for the National Institute for Health Quality Control and its director, Eduardo Peixoto, outlined the institute's main role - that of "moderating the free flow of licensing of pharmaceutical products in Brazil', Such steps are clearly needed, but the institute's predecessor, the National Secretariat for Health Vigilance (SNVS), given the responsibility for registering and controlling drugs six years ago, did not set a good precedent. Its Central Control Laboratory functioned for three years with only two technicians, at the end of which time it received its new name - and now after a further three years, a new building.

In the absence of effective controls, Brazil's pharmaceutical industry has gone on expanding despite the general economic recession, with the biggest growth area being psychotherapeutic drugs. Almost all drugs can be sold over the counter in any pharmacy without a prescription and the average consumption per person is several times greater than in developed countries.

One of the most alarming problems is the indiscriminate use of antibiotics. Antibiotics are routinely bought to treat colds, and with six of the ten best-selling drug products being antibiotics there have been many examples of falsification by private laboratories and distributors. The Maerson Laboratory of São Paulo was providing hospitals with "ziricillin" and "ampicillin" capsules which in fact contained pure starch. And in Rio de Janeiro, after a series of complaints from consumers, Roche Laboratories discovered that their Bactrim balsam had been the victim of large-scale falsification by distributors and that several Rio pharmacies were selling an adulterated product diluted to half its normal concentration. A further abuse of antibiotics came to light last November when the respected Adolfo Lutz Institute of Biology confirmed the accusation made by the president of the Pharmaceutical Association of São Paulo that the milk sold in São Paulo contained antibiotics used as preservatives.

In a recent report, Dr Carlyle Guerra de Macedo, a consultant to the World Health Organization, denounced the "inefficiency of official controls which permits the marketing of many dangerous drugs". Many drugs are still available in Brazil, even with no prescription, long after they have been prohibited in the United States. And many of the products on sale contain no warnings about the possible harmful effects of abuse. These problems are further complicated by the fact that in many pharmacies the staff are inadequately trained and know little about the products they sell.

The list of faults in the Brazilian way of marketing drugs is extensive, and the revitalized National Institute for Health Quality Control faces a daunting task.

Maurice Bazin 